\title{
Determination of acid, peroxide, and saponification value in patin fish oil by FTIR spectroscopy combined with chemometrics
}

\author{
${ }^{1}$ Putri, A.R., ${ }^{1,2, *}$ Rohman, A., ${ }^{3}$ Setyaningsih, W. and ${ }^{1}$ Riyanto, S. \\ ${ }^{1}$ Department of Pharmaceutical Chemistry, Faculty of Pharmacy, Universitas Gadjah Mada, Yogyakarta, \\ Indonesia \\ ${ }^{2}$ Institute of Halal Industry and Systems, Universitas Gadjah Mada, Yogyakarta 55281 Indonesia \\ ${ }^{3}$ Department of Food and Agricultural Product Technology, Faculty of Agricultural Technology, \\ Universitas Gadjah Mada, Jalan Flora No. 1, Bulaksumur, Depok, Sleman 55281 Yogyakarta, Indonesia
}

\begin{abstract}
Article history:
Received: 16 January 2020

Received in revised form: 17

March 2020

Accepted: 22 March 2020

Available Online: 15 April 2020
\end{abstract}

\section{Keywords:}

Acid value,

Peroxide value,

Saponification value,

Patin fish oil,

FTIR,

Chemometrics

\begin{abstract}
Simple, rapid, and reproducible methods for determining the acid value (AV), peroxide value (PV), and saponification value (SV) of patin fish oil (PFO) were developed using Fourier Transform Infrared (FTIR) spectroscopy combined with chemometrics of Principal Component Regression (PCR) and Partial Least Square (PLS). The relationship between actual values was determined using AOCS method and predicted value was determined with FTIR spectroscopy and chemometrics. From the validation work, the high coefficient of determination $\left(\mathrm{R}^{2}\right)$ reached up to $>0.99$. This study concluded that by means of FTIR spectra that combined with PCR and PLS technique can be used to determine $\mathrm{AV}, \mathrm{PV}$, and SV of PFO.
\end{abstract}

\section{DOI:}

https://doi.org/10.26656/fr.2017.4(5).030

\section{Introduction}

Patin (Pangasius micronemus) is a freshwater fish in Indonesia and have exported for years to the western market. Indonesia is the second largest of patin producer, with production reaching up to $16.1 \%$ of the total production of patin in the world (Ramadhan et al., 2016). Hashim et al. (2015) have sucessfully extracted fatty acid from patin and get lipid up to $31 \%$ with the level of omega-3 was $4.7 \%$. Hence, patin can be a good source of omega-3. While in Thailand and Vietnam, patin was extracted to obtain the fish oils and the patin fish oils (PFO) have been widely traded.

In the market, that is important to know the quality of fish oil. Some parameters used to determine the quality of fish oil. To determine the quality of fish oil can be performed by determining of physico-chemical values such as acid, peroxide, and saponification value (Rohman et al., 2015). Titration method was used to determine the acid, peroxide, and saponification value, based on the chemical reaction between free fatty acids and the reagent. But, the titration method has some disadvantages such as being time-consuming and laborintensive, requiring large amounts of organic solvents, use of the highly toxic, and carcinogenic reagent, difficulty in distinguishing the end-point with samples containing coloured substances and largely dependent on the skills of the analyst (Rohman et al., 2012; Jiang et al., 2016).

Currently, Fourier transform infrared spectroscopy (FTIR) combined with chemometrics has been widely used for determining acid, peroxide, and saponification value. FTIR has been used for determination of acid value on edible oil-based on -O-H stretching (Jiang et al., 2016), peroxide value on edible oils based on -COOstretching ( $\mathrm{Yu}$ et al., 2009; $\mathrm{Hu}$ et al., 2019), to monitoring peroxide value in oxidized emulsions (Hayati et al., 2005), and saponification value on red fruit oil using partial least square calibration (Rohman et al., 2015).

However, the application of FTIR spectroscopy for the determination of acid, peroxide, and saponification value of patin fish oil (PFO) has not been reported yet. Therefore, FTIR spectroscopy combined with principal component regression (PCR) and partial least square (PLS) was developed for the determination of acid, peroxide, and saponification value of PFO from some 
extraction methods.

\section{Materials and methods}

\subsection{Materials}

Patin from Tulungagung, East Java, Indonesia. Nhexane, chloroform, ethyl acetate, ethanol, $\mathrm{HCl}$, acetic acid, sodium thiosulphate, $\mathrm{KI}$, acetone, $\mathrm{KOH}$ were obtained from Merck (Germany), phenolphthalein indicator and starch from Progo Mulyo store in Yogyakarta.

\subsection{Extraction method}

Extractions of PFO were performed using maceration method with wet and dried samples and soxhlet method also with three variations of solvent are $n$ -hexane, ethyl acetate, and chloroform. The patin flesh was cutting into small pieces then extracted with the solvent for maceration with wet samples. Patin flesh was dried in the oven at $60^{\circ} \mathrm{C}$ for $24 \mathrm{hrs}$ before extracted using maceration with dried samples and Soxhlet method. Maceration process was performed at room temperature while the Soxhlet method at $82^{\circ} \mathrm{C}$. After the extraction step, the solvent was evaporated using the rotary evaporator at $50^{\circ} \mathrm{C}$ to get the $\mathrm{PFO}$.

\subsection{Acid value determination}

Determination of acid value using the AOCS official method Cd 3a-63 (AOCS, 2004). The oil sample (2 g) was mixed with $20 \mathrm{~mL}$ ethanol and added with $2 \mathrm{~mL}$ phenolphthalein in a $250 \mathrm{~mL}$ Erlenmeyer flask. The mixture was titrated with $0.01 \mathrm{M}$ of $\mathrm{KOH}$ and shaken vigorously until the color was changed (from white to pink). The result was expressed as the number of milligrams of $\mathrm{KOH}$ required to neutralize the free fatty acid in $1 \mathrm{~g}$ of the sample.

\subsection{Peroxide value determination}

Peroxide value is a measure of peroxides contained in the oil and is determined by measuring iodine released from potassium iodide. Determination of peroxide value was performed according to AOCS official method $\mathrm{Cd}$ 8b-90 (AOCS, 2005). The oil sample $(5 \pm 0.01 \mathrm{~g})$ was dissolved in $30 \mathrm{~mL}$ acetic acid-chloroform (3:2) solution. Then saturated KI solution and distilled water were added and shake the flask vigorously to liberate iodine from chloroform layer. The mixture was titrated with $0.01 \mathrm{~N}$ sodium thiosulphate using starch solution as an indicator.

\subsection{Saponification value determination}

The saponification value was expressed as the number of milligrams of potassium hydroxide $(\mathrm{KOH})$ required to saponify $1 \mathrm{~g}$ of oil. Determination of saponification value was according to AOCS method $\mathrm{Cd}$ 3-25 (AOCS, 1990). The $2 \mathrm{~g}$ of oil were dissolved with ethanol in Erlenmeyer flask. Then connected with an air condenser and boil gently for $1 \mathrm{hr}$ in order that sample is completely saponified. After it cooled and added $1 \mathrm{~mL}$ phenolphthalein. The mixture was titrated with $0.5 \mathrm{~N}$ $\mathrm{HCl}$ until the pink colour has just disappeared.

\subsection{FTIR analysis}

Samples were analysed using FTIR spectrometer (Thermo Scientific Nicolet iS10, Madison, WI) using Omnic software. The measurements were done in the middle infrared region of $650-4000 \mathrm{~cm}^{-1}$ with 32 scans and at the resolution was $16 \mathrm{~cm}^{-1}$. The background scan was performed to reduce the effect of the reference spectrum of the air. Before and after analysis sample, ATR crystal was cleaned with acetone p.a. Replications were done with scanning the same samples for three times.

\subsection{Data analysis}

Multivariate analysis of the acquired data was performed using principal component regression (PCR) and partial least square (PLS) with TQ Analyst software version 9 (Thermo Fisher Scientific Inc.) while the statistic analysis was done using Minitab 18. In this research, Principal component regression (PCR) and partial least square (PLS) were used to determine the physico-chemical value from FTIR spectral. PCR is one of inverse calibration technique in which the physicochemical value from titration method (x-axis) is used as a predictor, while responses such as absorbance at several wavelengths are located on the y-axis. PCR performs multiple inverse calibrations of predictor variables against the scores (knowns as principal components) rather than original variables (Rohman and Putri, 2019). Whereas the PLS method uses a correlation between changes in spectral absorption and sample concentration then computing with other spectra that can disturb the analyte spectra (Ballabio and Todeschini, 2009). In this research using normal, first derivative and second derivative spectra to identify the targeted spectra from the compounds by increasing the spectral resolution (Putri et al., 2019).

The collected data set was divided into calibration and validation subset. Prediction models were validated with cross validation 'leave one out' technique. Cross validation evaluates the data by excluding selected samples in the regression model and then constructing a new model for the remaining samples. The new model was evaluated and the error values for predicted observations are computed. The new samples are then 
excluded from the model set and a new model is constructed. This procedure is repeated until all samples in the PCR and PLS models have been excluded once (Rohman and Che Man, 2010). In order to compare the performances of the developed calibration models and express their predictive ability, two statistical values, namely root mean square error of calibration (RMSEC) and root mean square error of prediction (RMSEP) were calculated. Among these values, RMSEP gives the best estimation of future performance of the calibration model (Temiz et al., 2017).

\section{Results and discussion}

\subsection{FTIR Spectra of PFO}

The FTIR spectra of PFO was shown in Figure 1. Each peak corresponded to a functional group of fatty acid structure. The peak at wavenumber $721 \mathrm{~cm}^{-1}$ was due to the rocking vibration of methylene $\left(-\mathrm{CH}_{2}\right)$, while the peaks at 1114 and $1234 \mathrm{~cm}^{-1}$ were from -C-O vibrations. The bending vibration of methylene was observed at wavenumber $1461 \mathrm{~cm}^{-1}$. Meanwhile the carbonyl $(\mathrm{C}=\mathrm{O})$ stretching vibration was observed at a wavenumber $1744 \mathrm{~cm}^{-1}$. The peaks at wavenumbers 2854 and $2921 \mathrm{~cm}^{-1}$ represent asymmetric and symmetric stretching vibration of methylene $\left(-\mathrm{CH}_{2}\right)$ respectively (Rohman et al., 2011; Putri et al., 2019).

\subsection{Determination of $A V$}

The acid value (AV) is an explanatory parameter for evaluation of the level of hydrolysis of oil. Free fatty acid and glycerol were the results of the hydrolysis reaction. The acid value usually can be determined by acid/base titration (Mahboubifar et al., 2016). The AV from both titration and FTIR methods were shown in Table 1. The AVs from FTIR were obtained from optimization method (Table 2). Based on the ANOVA test using Minitab 18, p-value from both methods was 0.00 . So, the result from both methods not significantly different $(\mathrm{p}<0.05)$. The AV from the Soxhlet method were higher than in the maceration method. According to FAO about the standard for fish oils (2017), the acceptable of AV on fish oil is $\leq 3 \mathrm{mg} \mathrm{KOH} / \mathrm{g}$. The high of $\mathrm{AV}$ can be caused by heat treatment while in the extraction process. The heat treatment cause oxidation and hydrolysis on PFO to produce free fatty acid (Herchi et al., 2016).

According to Table 2, the PCR technique gave the best result than others. The wavenumber of 2000-3100 $\mathrm{cm}^{-1}$ was chosen to determine AV because give the highest coefficient determination for calibration and validation, 0.9879 and 1.000 respectively with the lowest RMSEC and RMSEP were 0.210 and 0.972 .

Figure 2 presents the linear regression of the PCR method expressing the relationship between AVs from the titration method (as actual value) and FTIR spectral (as calculated value). The peak at wavenumber of 2000$3100 \mathrm{~cm}^{-1}$ corresponding to the stretching vibration of cis $-\mathrm{C}=\mathrm{H}$ at $3006 \mathrm{~cm}^{-1}$ and vibration of $\mathrm{CH}_{2}$ stretching at the peak at 2854 and $2921 \mathrm{~cm}^{-1}$ from free fatty acid (Che Man et al., 2010) (Figure 3).

\subsection{Determination of $P V$}

Peroxide value (PV) is used to measure the level of peroxide/hydroperoxide formed at the initial process of oil oxidation by measuring iodine released from potassium iodide on titration process (Nunes, 2014; Naz and Saeed, 2018). The PVs of PFO by titration and FTIR combined with PCR method was shown in Table 1. Based on the ANOVA test, the PVs from titration and FTIR method were not significantly different $(p<0.05)$. The accuracy of iodometric titration to determine the PVs depends on some other experimental factors such as precise timing and protection of the reaction mixture from oxygen (Armenta et al., 2007). Determination of PVS by titration method could have an error caused by

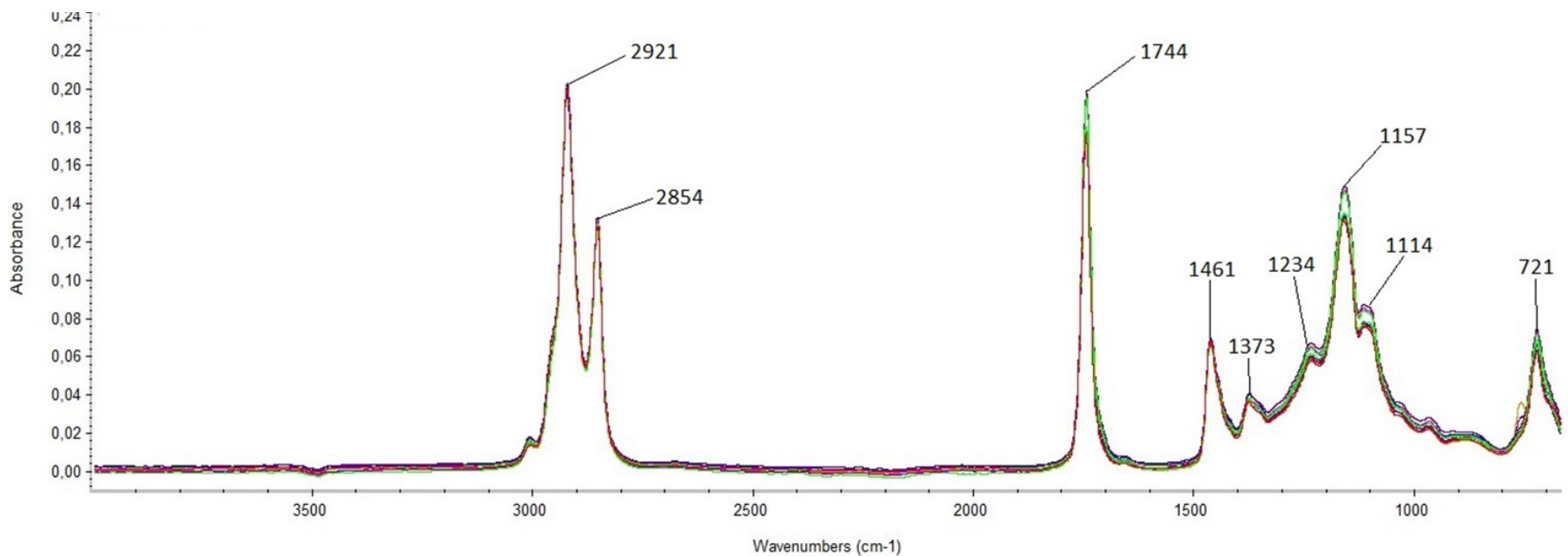

Figure 1. FTIR spectra of Patin fish oil from different extraction method at mid infrared region $\left(4000-650 \mathrm{~cm}^{-1}\right) \mathrm{scanned}$ with resolution of $16 \mathrm{~cm}^{-1}$ and number of scanning of 32 . 
Table 1. Determined of acid, peroxide, and saponification value by titration and FTIR methods after optimization method

\begin{tabular}{clcccccc}
\hline \multirow{2}{*}{ Extraction methods } & \multirow{2}{*}{ Solvent } & \multicolumn{2}{c}{ Acid Value } & \multicolumn{2}{c}{ Peroxide value } & \multicolumn{2}{c}{ Saponification value } \\
\cline { 3 - 7 } & & Titration & FTIR & Titration & FTIR & Titration & FTIR \\
\hline \multirow{2}{*}{$\begin{array}{c}\text { Maceration methods } \\
\text { (wet samples) }\end{array}$} & Hexane & 5.27 & 5.42 & 9.59 & 9.48 & 135.21 & 142.48 \\
& Chloroform & 2.66 & 2.71 & 7.18 & 7.16 & 287.71 & 288.79 \\
& Ethyl acetate & 7.01 & 7.36 & 9.61 & 9.51 & 221.74 & 220.8 \\
\hline \multirow{2}{*}{$\begin{array}{c}\text { Maceration method } \\
\text { (dried samples) }\end{array}$} & Hexane & 5.27 & 5.14 & 13.18 & 12.96 & 137.83 & 132.63 \\
& Chloroform & 8.86 & 8.88 & 13.18 & 12.97 & 287.64 & 284.41 \\
& Ethyl acetate & 10.57 & 10.84 & 13.16 & 13.5 & 187.84 & 189.93 \\
\hline \multirow{2}{*}{ Soxhlet } & Hexane & 15.6 & 15.67 & 8.38 & 8.52 & 144.28 & 145.44 \\
& Chloroform & 8.84 & 8.75 & 17.92 & 17.96 & 268.59 & 265.31 \\
& Ethyl acetate & 12.41 & 12.35 & 14.3 & 14.44 & 192.05 & 190.17 \\
\hline
\end{tabular}

Table 2. Optimization of PCR and PLS methods to determine the acid value

\begin{tabular}{|c|c|c|c|c|c|c|}
\hline \multirow{2}{*}{ Multivariate Calibration } & \multirow{2}{*}{ Wavenumber $\left(\mathrm{cm}^{-1}\right)$} & \multirow{2}{*}{ Spectra } & \multicolumn{2}{|c|}{ Calibration } & \multicolumn{2}{|c|}{ Prediction } \\
\hline & & & RMSEC & $\mathrm{R}^{2}$ & RMSEP & $\mathrm{R}^{2}$ \\
\hline \multirow{15}{*}{ PCR } & \multirow{3}{*}{$653-826$} & Normal & 1.78 & 0.8653 & 2.03 & 1.000 \\
\hline & & $1^{\text {st }}$ derivative & 3.56 & 0.0395 & 3.58 & 1.000 \\
\hline & & $2^{\text {nd }}$ derivative & 3.54 & 0.088 & 3.65 & 1.000 \\
\hline & \multirow{3}{*}{$1007-1600$} & Normal & 1.96 & 0.8344 & 1.96 & 1.000 \\
\hline & & $1^{\text {st }}$ derivative & 2.55 & 0.6969 & 3.57 & 1.000 \\
\hline & & $2^{\text {nd }}$ derivative & 3.19 & 0.4421 & 4.03 & 1.000 \\
\hline & \multirow{3}{*}{$1500-2111$} & Normal & 1.42 & 0.9171 & 2.33 & 1.000 \\
\hline & & $1^{\text {st }}$ derivative & 2.09 & 0.8088 & 0.361 & 1.000 \\
\hline & & $2^{\text {nd }}$ derivative & 2.07 & 0.8125 & 0.576 & 1.000 \\
\hline & \multirow{3}{*}{ 2000-3100 } & Normal & 0.21 & 0.9983 & 0.972 & 1.000 \\
\hline & & $1^{\text {st }}$ derivative & 0.6184 & 0.985 & 1.68 & 1.000 \\
\hline & & $2^{\text {nd }}$ derivative & 0.82 & 0.9731 & 1.5 & 1.000 \\
\hline & \multirow{3}{*}{$649-3005$} & Normal & 1.12 & 0.9488 & 2.2 & 1.000 \\
\hline & & $1^{\text {st }}$ derivative & 1.5 & 0.9068 & 0.666 & 1.000 \\
\hline & & $2^{\text {nd }}$ derivative & 1.59 & 0.8952 & 0.377 & 1.000 \\
\hline \multirow{15}{*}{ PLS } & \multirow{3}{*}{$653-826$} & Normal & 3.56 & 0.0383 & 3.57 & 1.000 \\
\hline & & $1^{\text {st }}$ derivative & 3.56 & 0.0271 & 3.57 & 1.000 \\
\hline & & $2^{\text {nd }}$ derivative & 3.56 & 0.0272 & 3.57 & 1.000 \\
\hline & \multirow{3}{*}{$1007-1600$} & Normal & 3.52 & 0.1491 & 3.97 & 1.000 \\
\hline & & $1^{\text {st }}$ derivative & 3.55 & 0.0744 & 3.78 & 1.000 \\
\hline & & $2^{\text {nd }}$ derivative & 3.55 & 0.0604 & 3.75 & 1.000 \\
\hline & \multirow{3}{*}{$1500-2111$} & Normal & 1.92 & 0.8424 & 1.75 & 1.000 \\
\hline & & $1^{\text {st }}$ derivative & 3.46 & 0.2276 & 3.9 & 1.000 \\
\hline & & $2^{\text {nd }}$ derivative & 3.5 & 0.1801 & 3.91 & 1.000 \\
\hline & \multirow{3}{*}{$2000-3100$} & Normal & 1.84 & 0.8564 & 2.04 & 1.000 \\
\hline & & $1^{\text {st }}$ derivative & 3.42 & 0.2778 & 4.07 & 1.000 \\
\hline & & $2^{\text {nd }}$ derivative & 3.45 & 0.2429 & 4.01 & 1.000 \\
\hline & \multirow{3}{*}{$649-3005$} & Normal & 3.4 & 0.2979 & 3.67 & 1.000 \\
\hline & & $1^{\text {st }}$ derivative & 3.48 & 0.205 & 3.91 & 1.000 \\
\hline & & $2^{\text {nd }}$ derivative & 3.47 & 0.2196 & 4.09 & 1.000 \\
\hline
\end{tabular}

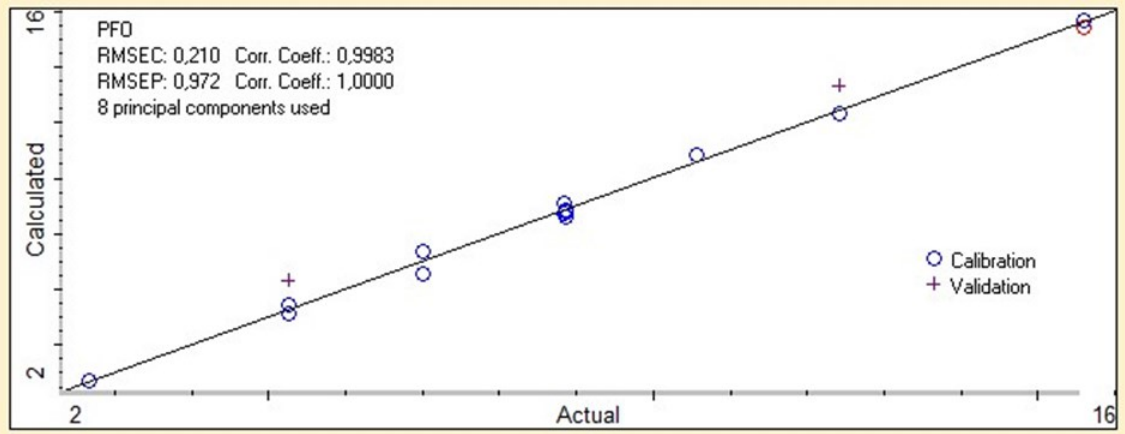

Figure 2. Plots of acid value result obtained by titration method (actual value) and FTIR method (calculated) in calibration and validation set using PCR technique 
the mistake of distinguishing on the endpoint (Jiang et al., 2016). Peroxide/hydroperoxide which is intermediate species. These intermediates are unstable species that can react very quickly that make the mistake when the determination of endpoint (Mahboubifar et al., 2016). The acceptable of PV for fish oil is $\leq 5 \mathrm{meq} \mathrm{O}_{2} / \mathrm{kg}$ oil (FAO, 2017). The oxidation rate increase with the temperature results high amount of peroxide, that make PVs of PFO from the Soxhlet method were highest than others (Popa et al., 2017).

Based on the optimization method, PLS with first derivative spectra showed the best result in the prediction of the desired response (Table 3). PLS at wavenumbers of $1500-2111 \mathrm{~cm}^{-1}$ were selected for determining the PVs because it gives the highest coefficient value for determination and validation. The coefficient value $\left(\mathrm{R}^{2}\right)$ of determination for the calibration and validation were obtained at 0.9982 . The RMSEC and RMSEP value were 0.200 and 0.564 respectively. The excellent linear relationship between the PVs measured by titration and FTIR method shown in Figure 4. Figure 5 presents the area $1500-2111 \mathrm{~cm}^{-1}$ is attributed for $-\mathrm{C}=\mathrm{O}$ ester stretching at wavenumber of $1700 \mathrm{~cm}^{-1}$ (Che Man et al., 2010). According to Guillén and Cabo (1999), under the oxidative conditions, the oils have a very intense absorption due to the ester carbonyl functional group of the triglycerides causes a peak at area $1746 \mathrm{~cm}^{-1}$. They also found that secondary oxidation products that cause an absorption at $1728 \mathrm{~cm}^{-1}$ which overlaps with the peak of the ester functional group.

\subsection{Determination of $S V$}

Saponification value (SV) is an index of the average molecular mass of fatty acid in the oil sample (Zahir et al., 2017). The SV of PFO was determined by titration and FTIR combined with PCR and PLS methods were shown in Table 1. Both methods give not significantly different result $(p<0,05)$. From the optimization method, the area at wavenumber of $1007-1600 \mathrm{~cm}^{-1}$ was chosen to determine PVs Table 4. The PLS method with first derivative spectra gave the best coefficient of determination for calibration and validation, 0.9970 and 1.000 respectively with the RMSEC and RMSEP were 4.54 and 4.45 . This is supported by the result of research

Table 3. Optimization of PCR and PLS methods to determine the peroxide value

\begin{tabular}{|c|c|c|c|c|c|c|}
\hline \multirow{2}{*}{ Multivariate Calibration } & \multirow{2}{*}{ Wavenumber $\left(\mathrm{cm}^{-1}\right)$} & \multirow{2}{*}{ Spectra } & \multicolumn{2}{|c|}{ Calibration } & \multicolumn{2}{|c|}{ Prediction } \\
\hline & & & RMSEC & $\mathrm{R}^{2}$ & RMSEP & $\mathrm{R}^{2}$ \\
\hline \multirow{15}{*}{ PCR } & \multirow{3}{*}{$653-826$} & Normal & 1.26 & 0.9256 & 1.85 & 0.8461 \\
\hline & & $1^{\text {st }}$ derivative & 1.41 & 0.9062 & 2.36 & 0.6824 \\
\hline & & $2^{\text {nd }}$ derivative & 1.41 & 0.9056 & 2.13 & 0.7450 \\
\hline & \multirow{3}{*}{$1007-1600$} & Normal & 1.57 & 0.8829 & 2.09 & 0.7716 \\
\hline & & $1^{\text {st }}$ derivative & 1.57 & 0.8827 & 2.29 & 0.7091 \\
\hline & & $2^{\text {nd }}$ derivative & 1.32 & 0.9184 & 1.60 & 0.8695 \\
\hline & \multirow{3}{*}{$1500-2111$} & Normal & 0.765 & 0.9733 & 0.599 & 0.9929 \\
\hline & & $1^{\text {st }}$ derivative & 1.91 & 0.8194 & 3.22 & 0.3592 \\
\hline & & $2^{\text {nd }}$ derivative & 1.47 & 0.8980 & 3.03 & 0.4763 \\
\hline & \multirow{3}{*}{$2000-3100$} & Normal & 1.26 & 0.9263 & 1.21 & 0.9605 \\
\hline & & $1^{\text {st }}$ derivative & 1.08 & 0.9460 & 2.23 & 0.7201 \\
\hline & & $2^{\text {nd }}$ derivative & 0.825 & 0.9689 & 2.40 & 0.6906 \\
\hline & \multirow{3}{*}{$649-3005$} & Normal & 0.998 & 0.9542 & 0.843 & 0.9869 \\
\hline & & $1^{\text {st }}$ derivative & 0.680 & 0.9790 & 0.330 & 0.9957 \\
\hline & & $2^{\text {nd }}$ derivative & 0.811 & 0.9700 & 0.642 & 0.9904 \\
\hline \multirow{15}{*}{ PLS } & \multirow{3}{*}{$653-826$} & Normal & 2.30 & 0.7255 & 2.82 & 0.7611 \\
\hline & & $1^{\text {st }}$ derivative & 2.02 & 0.7966 & 2.61 & 0.7397 \\
\hline & & $2^{\text {nd }}$ derivative & 2.13 & 0.7707 & 2.68 & 0.7493 \\
\hline & \multirow{3}{*}{$1007-1600$} & Normal & 1.81 & 0.8391 & 3.47 & 0.2069 \\
\hline & & $1^{\text {st }}$ derivative & 1.64 & 0.8707 & 2.79 & 0.5305 \\
\hline & & $2^{\text {nd }}$ derivative & 1.65 & 0.8695 & 2.81 & 0.5314 \\
\hline & \multirow{3}{*}{$1500-2111$} & Normal & 2.14 & 0.7680 & 1.88 & 0.8719 \\
\hline & & $1^{\text {st }}$ derivative & 0.200 & 0.9982 & 0.564 & 0.9982 \\
\hline & & $2^{\text {nd }}$ derivative & 0.683 & 0.9788 & 0.666 & 0.9871 \\
\hline & \multirow{3}{*}{$2000-3100$} & Normal & 1.80 & 0.8411 & 3.31 & 0.3054 \\
\hline & & $1^{\text {st }}$ derivative & 1.77 & 0.8485 & 3.52 & 0.2450 \\
\hline & & $2^{\text {nd }}$ derivative & 1.81 & 0.8402 & 3.61 & 0.1963 \\
\hline & \multirow{3}{*}{$649-3005$} & Normal & 2.25 & 0.7374 & 2.77 & 0.7514 \\
\hline & & $1^{\text {st }}$ derivative & 2.28 & 0.7297 & 2.82 & 0.7501 \\
\hline & & $2^{\text {nd }}$ derivative & 2.31 & 0.7211 & 2.86 & 0.7541 \\
\hline
\end{tabular}




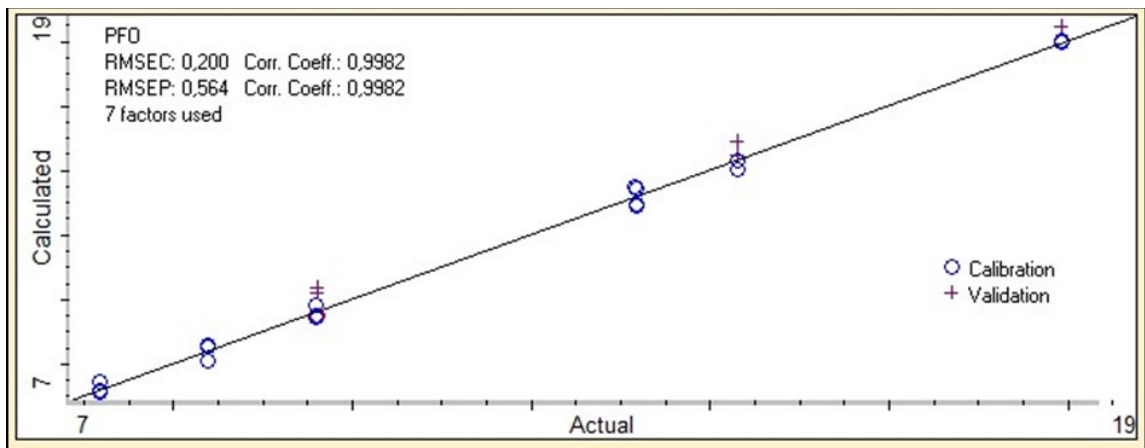

Figure 4. Plots of peroxide value result obtained by titration method (actual value) and FTIR method (calculated) in calibration and validation set using PLS technique

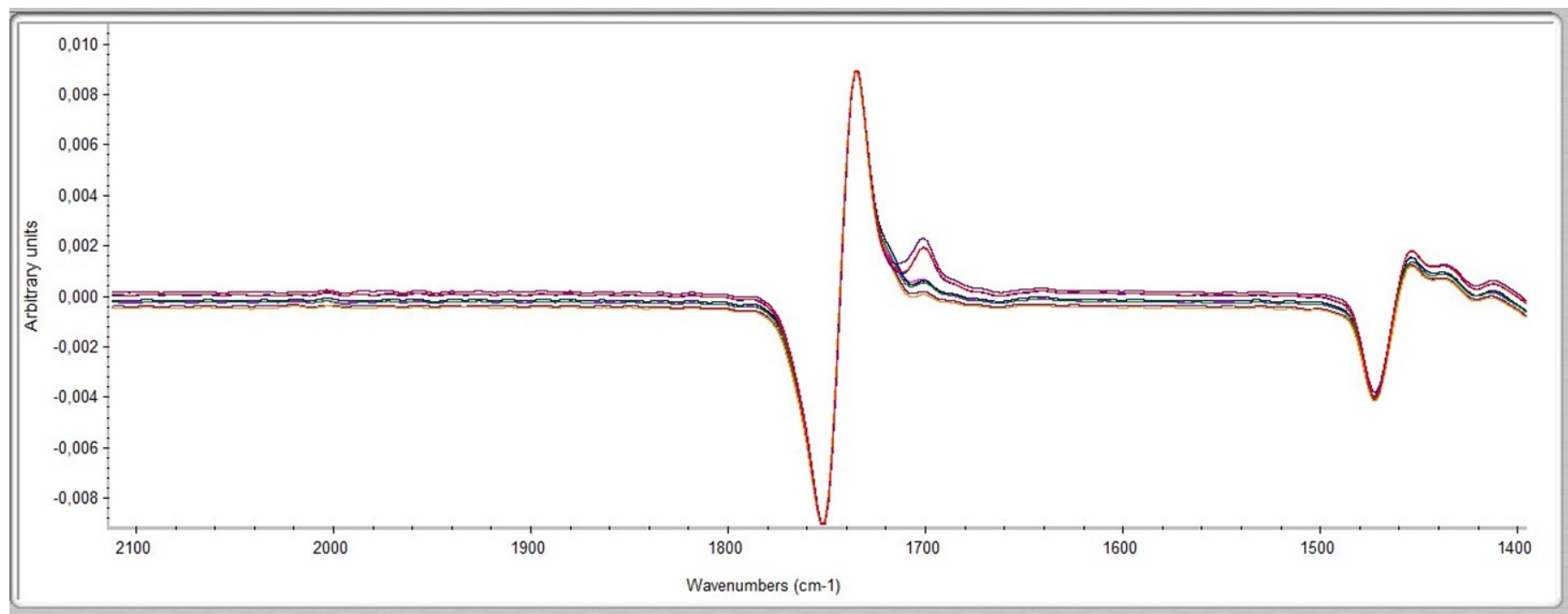

Figure 5. FTIR spectra to determine the peroxide value of Patin fish oil $\left(1500-2111 \mathrm{~cm}^{-1}\right)$

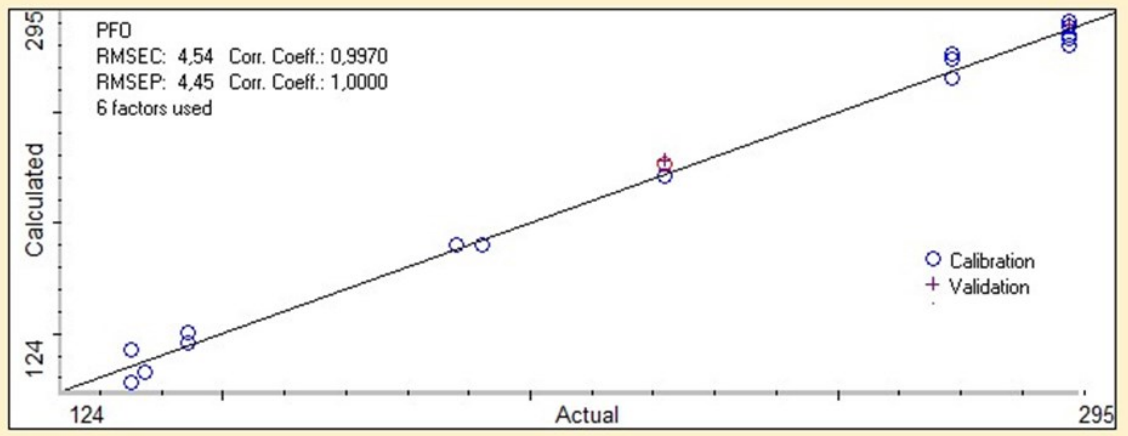

Figure 6. Plots of saponification value result obtained by titration method (actual value) and FTIR method (calculated)

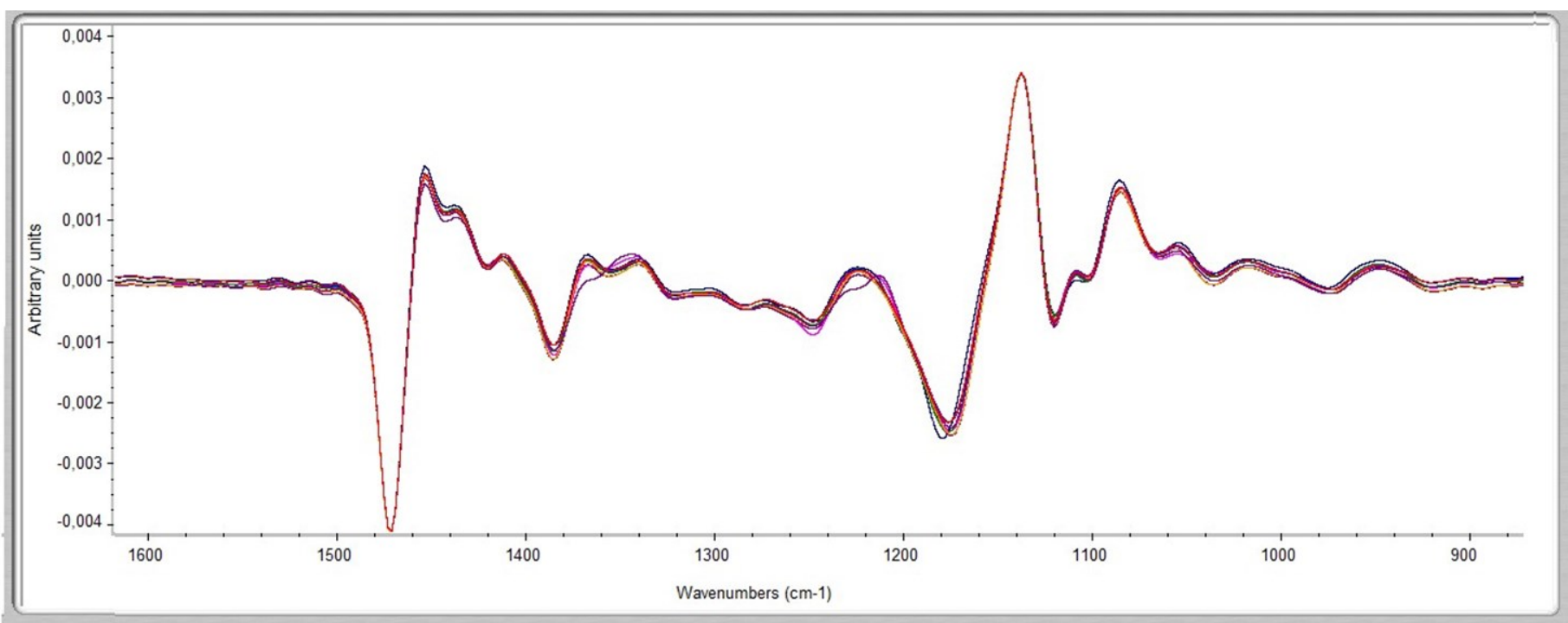

Figure 7. FTIR spectra to determine the saponification value of Patin fish oil (1007-1600 $\left.\mathrm{cm}^{-1}\right)$ 
Table 4. Optimization of PCR and PLS methods to determine the saponification value

\begin{tabular}{|c|c|c|c|c|c|c|}
\hline \multirow{2}{*}{ Multivariate Calibration } & \multirow{2}{*}{ Wavenumber $\left(\mathrm{cm}^{-1}\right)$} & \multirow{2}{*}{ Spectra } & \multicolumn{2}{|c|}{ Calibration } & \multicolumn{2}{|c|}{ Prediction } \\
\hline & & & RMSEC & $\mathrm{R}^{2}$ & RMSEP & $\mathrm{R}^{2}$ \\
\hline \multirow{15}{*}{ PCR } & \multirow{3}{*}{$653-826$} & Normal & 39.6 & 0.7412 & 57.6 & 1.000 \\
\hline & & $1^{\text {st }}$ derivative & 40.0 & 0.7337 & 57.0 & 1.000 \\
\hline & & $2^{\text {nd }}$ derivative & 41.3 & 0.7131 & 59.6 & 1.000 \\
\hline & \multirow{3}{*}{$1007-1600$} & Normal & 14.9 & 0.9674 & 176 & 1.000 \\
\hline & & $1^{\text {st }}$ derivative & 19.2 & 0.9453 & 12.5 & 1.000 \\
\hline & & $2^{\text {nd }}$ derivative & 24.3 & 0.9112 & 18.4 & 1.000 \\
\hline & \multirow{3}{*}{$1500-2111$} & Normal & 22.8 & 0.9221 & 46.3 & 1.000 \\
\hline & & $1^{\text {st }}$ derivative & 31.0 & 0.8507 & 53.6 & 1.000 \\
\hline & & $2^{\text {nd }}$ derivative & 26.6 & 0.8924 & 42.8 & 1.000 \\
\hline & \multirow{3}{*}{$2000-3100$} & Normal & 9.14 & 0.9879 & 16.7 & 1.000 \\
\hline & & $1^{\text {st }}$ derivative & 18.3 & 0.9508 & 29.5 & 1.000 \\
\hline & & $2^{\text {nd }}$ derivative & 21.5 & 0.9310 & 30.9 & 1.000 \\
\hline & \multirow{3}{*}{$649-3005$} & Normal & 8.17 & 0.9902 & 9.54 & 1.000 \\
\hline & & $1^{\text {st }}$ derivative & 9.84 & 0.9860 & 6.03 & 1.000 \\
\hline & & $2^{\text {nd }}$ derivative & 9.82 & 0.9860 & 4.11 & 1.000 \\
\hline \multirow{15}{*}{ PLS } & \multirow{3}{*}{$653-826$} & Normal & 44.8 & 0.6501 & 70.2 & 1.000 \\
\hline & & $1^{\text {st }}$ derivative & 44.6 & 0.6527 & 71.0 & 1.000 \\
\hline & & $2^{\text {nd }}$ derivative & 44.4 & 0.6569 & 71.2 & 1.000 \\
\hline & \multirow{3}{*}{$1007-1600$} & Normal & 13.8 & 0.9721 & 15.2 & 1.000 \\
\hline & & $1^{\text {st }}$ derivative & 4.54 & 0.9970 & 4.45 & 1.000 \\
\hline & & $2^{\text {nd }}$ derivative & 18.2 & 0.95113 & 10.3 & 1.000 \\
\hline & \multirow{3}{*}{$1500-2111$} & Normal & 21.3 & 0.9321 & 45.3 & 1.000 \\
\hline & & $1^{\text {st }}$ derivative & 36.8 & 0.7811 & 67.4 & 1.000 \\
\hline & & $2^{\text {nd }}$ derivative & 35.5 & 0.7983 & 64.0 & 1.000 \\
\hline & \multirow{3}{*}{$2000-3100$} & Normal & 8.96 & 0.9884 & 15.6 & 1.000 \\
\hline & & $1^{\text {st }}$ derivative & 16.4 & 0.9606 & 27.2 & 1.000 \\
\hline & & $2^{\text {nd }}$ derivative & 17.1 & 0.9571 & 25.8 & 1.000 \\
\hline & \multirow{3}{*}{$649-3005$} & Normal & 45.1 & 0.6444 & 70.2 & 1.000 \\
\hline & & $1^{\text {st }}$ derivative & 45.0 & 0.6462 & 70.8 & 1.000 \\
\hline & & $2^{\text {nd }}$ derivative & 45.0 & 0.6462 & 70.8 & 1.000 \\
\hline
\end{tabular}

conducted by Rohman et al. (2015) that use absorbance at wavelength of $1400-1600 \mathrm{~cm}^{-1}$ with PLS technique to determine the SVs. The linear regression as shown in Figure 6. First derivative spectra were displayed in Figure 7.

\section{Conclusion}

In this work, the AV, PV, and SV of PFO were successfully determined via FTIR spectroscopy combined with chemometrics using PCR and PLS method. The rapid determination of $\mathrm{AV}, \mathrm{PV}$, and $\mathrm{SV}$ by FTIR spectroscopy is, therefore, suitable and practical option for process control. Another advantage of FTIR spectroscopy method is that it is environmentally friendly as no chemical is needed except acetone for cleaning the ATR crystal. By utilizing this method, the chemical cost is negligible as compared to the AOCS standard method.

\section{Conflict of interest}

The authors declare no conflict of interest.

\section{Acknowledgment}

The author thanks to The Ministry of Research, Technology, and Higher Education of the Republic of Indonesia for its scholarship so that this research can be done.

\section{References}

AOCS. (1990) Determination of saponification value. Champaign, USA: AOCS Publishing

AOCS. (2004). Official methods and recommended practices of the American Oil Chemists' Society. Champaign, USA: AOCS Publishing.

AOCS. (2005). Official Methods of Analysis Cd 8b-90. Champaign, USA: AOCS Publishing.

Armenta, S., Garrigues, S. and de la Guardia, M. (2007). Determination of edible oil parameters by near infrared spectrometry. Analytica Chimica Acta, 596 (2), 330-337. https://doi.org/10.1016/ j.aca.2007.06.028

Ballabio, D. and Todeschini, R. (2009). Multivariate 
classification for qualitative analysis. In Sun, D.W. (Ed). Infrared Spectroscopy for Food Quality Analysis and Control. London: Elsevier. https:// doi.org/10.1016/B978-0-12-374136-3.00004-3

Che Man, Y.B, Syahariza, Z.A. and Rohman, A. (2010). Chapter 1. Fourier transform infrared (FTIR) spectroscopy: development, techniques, and application in the analyses of fats and oils. New York: Nova Science Publisher.

FAO. (2017). Standards for Fish Oils. Italy: Codex Alimentarius Commission.

Guillén, M.D. and Cabo, N. (1999). Usefulness of the Frequency Data of the Fourier Transform Infrared Spectra to Evaluate the Degree of Oxidation of Edible Oils. Journal of Agricultural and Food Chemistry, 47(2), 709-719. https://doi.org/10.1021/ jf9808123

Hashim, R.B., Jamil, E.F., Zulkipli, F.H. and Daud, J.M. (2015). Fatty Acid Compositions of Silver Catfish, Pangasius sp. Farmed in Several Rivers of Pahang, Malaysia. Journal of Oleo Science, 64(2), 205-209. http://doi.org/10.5650/jos.ess14191

Hayati, I.N., Man, Y.B.C., Tan, C.P. and Aini, I.N. (2005). Monitoring peroxide value in oxidized emulsions by Fourier transform infrared spectroscopy. European Journal of Lipid Science and Technology, 107(12), 886-895. https:// doi.org/10.1002/ejlt.200500241

Herchi, W., Ammar, K.B., Bouali, I., Abdallah, I.B., Guetet, A. and Boukhchina, S. (2016) . Heating effects on physicochemical characteristics and antioxidant activity of flaxseed hull oil (Linum usitatissimum L). Food Science and Technology, 36 (1), 97-102. http://dx.doi.org/10.1590/1678457X.0109

Hu, K., Huyan, Z., Geng, Q. and Yu, X. (2019). Rapid Determination of Acid Value of Edible Oils via FTIR Spectroscopy Using Infrared Quartz Cuvette. Journal of Oleo Science, 68(2), 121-129. https:// doi.org/10.5650/jos.ess 18156

Jiang, X., Li, S., Xiang, G., Li, Q., Fan, L., He, L. and $\mathrm{Gu}$, K. (2016). Determination of the acid values of edible oils via FTIR spectroscopy based on the $\mathrm{OH}$ stretching band. Food Chemistry, 212, 585-589. https://doi.org/10.1016/j.foodchem.2016.06.035

Mahboubifar, M., Yousefinejad, S., Alizadeh, M. and Hemmateenejad, B. (2016). Prediction of the acid value, peroxide value and the percentage of some fatty acids in edible oils during long heating time by chemometrics analysis of FTIR-ATR spectra. Journal of the Iranian Chemical Society, 13(12), 2291-2299. https://doi.org/10.1007/s13738-016-0948
$-1$

Naz, S. and Saeed, R. (2018). Oxidative Stability of Canola Oil by Physico-Chemical Analysis and FTIR Spectroscopy. Asian Journal of Pharmaceutical Research and Development, 6(1), 9-15. https:// doi.org/10.22270/ajprd.v6i1.353

Nunes, C.A. (2014). Vibrational spectroscopy and chemometrics to assess authenticity, adulteration and intrinsic quality parameters of edible oils and fats. Food Research International, 60, 255-261. https:// doi.org/10.1016/j.foodres.2013.08.041

Popa, M., Glevitzky, I., Dumitrel, G.-A., Glevitzky, M. and Popa, D. (2017). Study on Peroxide Values for Different Oils and Factors Affecting the Quality of Sunflower Oil. Papers-Series E-Land Reclamation Earth Observation and Surveying Environmental Engineering, 6, 137-140. https://doi.org/10.1016/ j.foodres.2013.08.041

Putri, A.R., Rohman, A. and Riyanto, S. (2019). Authentication of Patin (Pangasius micronemus) Fish Oil Adulterated with Palm Oil Using FTIR Spectroscopy Combined With Chemometrics. International Journal of Applied Pharmaceutics, 11 (3) 195-199. http://dx.doi.org/10.22159/ ijap.2019v11i3.30947

Ramadhan, A., Suwandi, R. and Trilaksani, W. (2016). Competitiveness Strategies of Indonesia Pangasius Fillet. Indones. Indonesian Journal of Business and Entrepreneurship, 2(2), 82. https://doi.org/10.17358/ ijbe.2.2.82

Rohman, A. and Che Man, Y.B.C. (2010). Fourier transform infrared (FTIR) spectroscopy for analysis of extra virgin olive oil adulterated with palm oil. Food Research International, 43(3), 886-892. https://doi.org/10.1016/j.foodres.2009.12.006

Rohman, A. and Putri, A.R. (2019). The Chemometrics Techniques in Combination with Instrumental Analytical Methods Applied in Halal Authentication Analysis. Indonesian Journal of Chemistry, 19(1), 262-272. https://doi.org/10.22146/ijc.28721

Rohman, A., Che Man, Y.B., Hashim, P. and Ismail, A. (2011). FTIR spectroscopy combined with chemometrics for analysis of lard adulteration in some vegetable oils. Cyta-Journal of Food, 9(2), 96101. https://doi.org/10.1080/19476331003774639

Rohman, A., Riyanto, S. and Che Man, Y.B. (2012). Characterizaton of red fruit (Pandanus conoideus Lam) oil 5. International Food Research Journal, 19 (2), 563-567.

Rohman, A., Triyasmono, L., Riyanto, S. and Andina, L. (2015). Rapid Determination of Saponification Value in Red Fruit Oil by Infrared Spectroscopy and 
Partial Least Square Calibration. Research Journal of Medicinal Plant, 9, 442-448. https:// doi.org/10.3923/rjmp.2015.442.448

Temiz, H.T., Tamer, U., Berkkan, A. and Boyaci, I.H. (2017). Synchronous fluorescence spectroscopy for determination of tahini adulteration. Talanta, 167, $557-562$.

https://doi.org/10.1016/

j.talanta.2017.02.044

Yu, X., Du, S., Voort, F.R. van de, Yue, T. and Li, Z. (2009). Automated and Simultaneous Determination of Free Fatty Acids and Peroxide Values in Edible Oils by FTIR Spectroscopy Using Spectral Reconstitution. Analytical Sciences, 25(5), 627-632. https://doi.org/10.2116/analsci.25.627

Zahir, E., Saeed, R., Hameed, M.A. and Yousuf, A. (2017). Study of physicochemical properties of edible oil and evaluation of frying oil quality by Fourier Transform-Infrared (FT-IR) Spectroscopy. Arabian Journal of Chemistry, 10(Supplement 2), S3870-S3876. https://doi.org/10.1016/ j.arabjc.2014.05.025 